\section{Combined Action of Purothionin and Thioredoxin on the Refolding of Recombinant Pro-urokinase}

\author{
Katsuzumi Okumura, Hideto Wakayama, \\ Yoshiaki MiYake, Hiroshi TaguchI \\ and Yoshihide SHImabayashi \\ Laboratory of Biological Chemistry, Faculty \\ of Bioresources, Mie University, Tsu, \\ Mie 514, Japan
}

Received April 7, 1989

Recombinant proteins cloned and expressed in bacteria often form inclusion bodies. As they exist in an insoluble and inactive form, the refolding to their native forms is one of the urgent problems in genetic engineering. When the recombinant protein has several disulfide bonds, it is necessary to form native-paired disulfides to obtain the biologically active form. " We have reported that thioldisulfide interchange proteins, protein disulfide-isomerase or thioredoxin, have positive effects on the refolding promotion of the recombinant protein. ${ }^{2,3)}$ In this paper, we examined the synergistic effects of purothionin on the thioredoxin-catalyzed refolding of recombinant human pro-urokinase.

Purothionin, which is a basic protein containing four disulfide bridges, ${ }^{4)}$ occurs in the seed endosperm of cereals such as wheat, barley, and rye. ${ }^{5,6)}$ This protein is suggested to interact with thioredoxin in cereals and to have the possibility of acting as a secondary thiol messenger in the redox regulation of enzymes. $\left.{ }^{7} 8\right)$ On the combined action of wheat purothionin and bacterial thioredoxin, there are a few reports, such as the activation of chloroplast fructose-1,6-bisphosphatase by the reduction of the active site disulfide. ${ }^{8)}$ In this paper, we report for the first time that these two proteins act synergistically on the refolding of recombinant protein.

Purothionin (from wheat) and thioredoxin (from Escherichia coli) were obtained from Takara Shuzo Co., Ltd. The insoluble pellet of sonicated bacteria expressed recombinant pro-urokinase was a gift from Tosoh Co., Ltd. Construction of an expression plasmid of human prourokinase, ${ }^{9}$ its refolding conditions, ${ }^{2,3)}$ and assay of urokinase activity ${ }^{10)}$ are described in each reference.

Our previous report showed that the effects of thioredoxin on the refolding of the reduced form of pro-urokinase were larger than that on the refolding of pro-urokinase without reduction. ${ }^{3)}$ So, we examined the effects of purothionin on the pro-urokinase refolding using its reduced form. Additional effects of purothionin on the refolding system of reduced pro-urokinase containing thioredoxin were compared in the presence or absence of the proper glutathione redox state as mentioned in Table I. Purothionin was less effective than thioredoxin on the reduced pro-urokinase refolding whether the glutathione redox was adjusted or not. But a larger effect was observed when both purothionin and thioredoxin were added to the refolding system and was compared with each system alone. This effect was particularly large in the system without glutathione. This result shows that the proper redox state of glutathione is not necessary to refold reduced pro-urokinase to the native form.

Synergistic effects of purothionin and thioredoxin were investigated with the refolding system of reduced prourokinase without glutathione (Fig. 1). When purothionin was added to the refolding system containing the definite concentration of thioredoxin, the promoting effect on the refolding was saturated with about $50 \mu \mathrm{M}$ purothionin (Fig. 1(A)). On the other hand, the additional effect of purothionin was raised according to the thioredoxin concentration, when $50 \mu \mathrm{M}$ purothionin was added to the thioredoxin-refolding system (Fig. 1(B)). This effect was approximately saturated with the addition of both $50 \mu \mathrm{M}$ purothionin and $100 \mu \mathrm{M}$ thioredoxin. In this case, most of the pro-urokinase contained in this system would be refolded to its native form.

We reported here, for the first time, the combined action of these two proteins on the recombinant protein refolding. Thioredoxin has been reported to catalyze the thioldisulfide exchange reaction, ${ }^{11)}$ but there has been no such a

\section{Table I. Synergistic Effects of Purothionin AND THIOREDOXIN ON THE REFOLDING OF REDUCED PRO-UROKINASE}

Additional effects of purothionin and thioredoxin were examined in the presence or absence of glutathione. The final concentration of additional agents was $50 \mu \mathrm{m}$ thioredoxin, $50 \mu \mathrm{m}$ purothionin, and both $1 \mathrm{~mm}$ of the reduced form and $0.1 \mathrm{~mm}$ of the oxidized form of glutathione. The refolding was started by adding reduced pro-urokinase and was done at $25^{\circ} \mathrm{C}$. After three hours, a portion was taken out and the urokinase activity was measured. The percentage of each sample was calculated from the ratio to the regained urokinase activity of the system containing only glutathione.

\begin{tabular}{lrc}
\hline & \multicolumn{2}{c}{ Relative refolding $(\%)$} \\
\cline { 2 - 3 } Addition & - Glutathione & + Glutathione \\
\hline None & 51 & 100 \\
+ Thioredoxin & 131 & 251 \\
+ Purothionin & 72 & 152 \\
+ Thioredoxin, & 277 & 290 \\
Purothionin & & \\
\hline
\end{tabular}


(A)

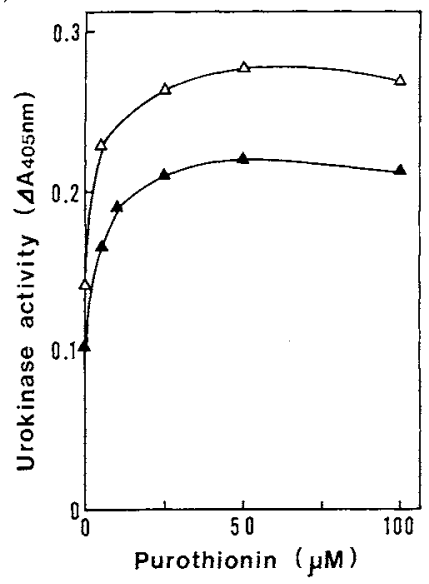

(B)

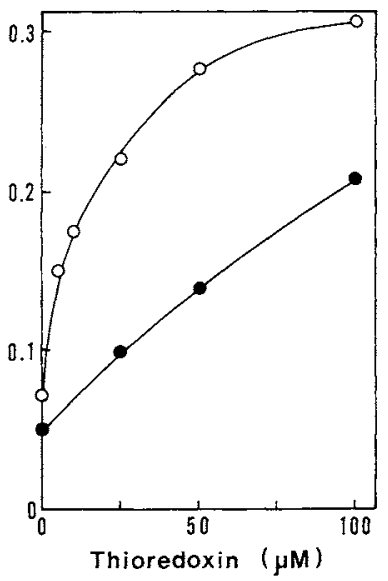

Fig. 1. The Dependence of Reduced Pro-urokinase Refolding on Purothionin and Thioredoxin concentration in the Absence of Glutathione.

(A): $25 \mu \mathrm{M}(\mathbf{\Delta})$ or $50 \mu \mathrm{m}(\triangle)$ thioredoxin was mixed with each concentration of purothionin. (B): thioredoxin only; $(\bigcirc)$, added $50 \mu \mathrm{m}$ purothionin. After three hours of incubation, a portion of the refolding mixture was taken out and the urokinase activity was assayed and plotted.

report about purothionin. As purothionin has four disulfide bridges, they might be concerned with the refolding promotion. Purothionin, like glutathione, would adjust the redox state by interacting with thioredoxin.

Acknowledgments. We wish to thank Biotechnology Research Labo., Tosoh Co., Ltd., for the recombinant pro-urokinase.

This work was supported in part by a Grant-in-Aid from the Okasan-Kato Culture and Science Foundation.

\section{References}

1) H. L. Heyneker, W. E. Holmes and G. A. Vehar, European Patent Application, Publ. No. 0092182 (1983)

2) K. Okumura, Y. Miyake, H. Wakayama, T. Miyake, K. Murayama, K. Seto, H. Taguchi and Y. Shimabayashi, Agric. Biol. Chem., 52, 1735 (1988).

3) K. Okumura, H. Wakayama, Y. Miyake, K.
Murayama, T. Miyake, K. Seto, H. Taguchi and Y. Shimabayashi, Agric. Biol. Chem., 52, 2969 (1988).

4) S. Ohtani, T. Okada, H. Kagamiyama and H. Yoshizumi, Agric. Biol. Chem., 39, 2269 (1975).

5) D. G. Redman and N. Fischer, J. Sci. Food Agric., 20, 427 (1969).

6) C. Hernandes-Lucas, P. Carbonera and F. GarciaOlmedo, J. Agric. Food Chem., 26, 794 (1978).

7) K. Wada and B. B. Buchanan, FEBS Lett., 124, 237 (1981).

8) T. C. Johnson, K. Wada, B. B. Buchanan and A. Holmgren, Plant Physiol., 85, 446 (1987).

9) Y. Hibino, T. Miyake, Y. Kobayashi, M. Ohmori, T. Miki, R. Matsumoto, N. Numao and K. Kondo, Agric. Biol. Chem., 52, 329 (1988).

10) T. Kohno, P. Hopper, J. S. Lillquist, R. L. Suddith, R. Greenlee and D. T. Moir, BIO/TECHNOLOGY, 2, 628 (1984).

11) V. P. Pigiet and B. J. Schuster, Proc. Natl. Acad. Sci. U.S.A., 83, 7643 (1986). 